\title{
ANALISIS KECEMASAN MAHASISWA DALAM MENYELESAIKAN SKRIPSI
}

\section{Husni Wakhyudin dan Anggun Dwi Setya Putri}

Universitas PGRI Semarang

Email: husni.wakhyu@yahoo.co.id

\section{Info Artikel}

\section{Sejarah Artikel:}

Diserahkan 15 April 2020

Direvisi 22 Juni 2020

Disetujui 22 Juni 2020

\section{Keywords:}

anxiety,

students,

supervisor,

thesis

\section{Abstract}

The purpose of this study is to analyze the anxiety of communicating students with the supervisor in the thesis guidance process.

This research method uses qualitative methodology. Data collection techniques used were questionnaire, interview, observation and documentation.

The results showed that the anxiety of communicating students in the experience of communication interaction with the supervisor in the thesis guidance process occurred in students when compiling or doing thesis guidance. This results in students experiencing various kinds of anxiety, ranging from headaches, difficulty falling asleep, feeling tired, restlessness, nervousness, despair, depression, dizziness, thoughts become chaotic so that it impacts on others so that they become targets of anger. Factors that have the potential to be the cause of student anxiety in communication interactions with supervisors in the guidance process are internal and external factors.

\begin{abstract}
Abstrak
Tujuan dari penelitian ini adalah menganalisis kecemasan berkomunikasi mahasiswa dengan dosen pembimbing dalam proses bimbingan skripsi.

Metode penelitian ini menggunakan metodologi kualitatif. Teknik pengumpulan data yang digunakan adalah kuesioner, wawancara, observasi dan dokumentasi.

Hasil penelitian menunjukkan bahwa kecemasan berkomunikasi mahasiswa dalam pengalaman interaksi komunikasi dengan dosen pembimbing dalam proses bimbingan skripsi terjadi pada mahasiswa ketika menyusun maupun melakukan bimbingan skripsi. Hal tersebut mengakibatkan mahasiswa mengalami berbagai macam kecemasan, mulai dari sakit kepala, sulit tidur, cepat merasa lelah, gelisah, gugup, putus asa, depresi, pusing, pikiran menjadi kacau sehingga berdampak pada orang lain sehingga menjadi sasaran kemarahan. Faktor-faktor yang berpotensi menjadi penyebab terjadinya kecemasan mahasiswa dalam interaksi komunikasi dengan dosen pembimbing dalam proses bimbingan yakni faktor internal dan faktor eksternal.
\end{abstract}


Husni Wakhyudin, dan Anggun Dwi Setya Putri

ANALISIS KECEMASAN MAHASISWA DALAM MENYELESAIKAN SKRIPSI

WASIS: Jurnal Ilmiah Pendidikan. Volume 1, Nomor 1, Mei 2020, hlm. 14-18

\section{PENDAHULUAN}

Perguruan tinggi sebagai titik tertinggi dari tingkat pendidikan formal dimana mahasiswa akan mempersiapkan kemampuannya sebelum masuk dalam kehidupan nyata. Secara prosedural, kemampuan dan kesiapan mahasiswa akan diuji dengan tugas akhir berupa skripsi sebagai syarat untuk mendapat gelar sarjana. Skripsi merupakan bukti integritas mahasiswa sebagai wujud implementasi ilmu yang telah diperoleh di perguruan tinggi. Selain itu, skripsi sebagai karya tertinggi mahasiswa Strata satu (S-1) yang melibatkan rasa dan karsa serta kemampuan intelijen dan emosional. Hal tersebut dikarenakan mahasiswa dituntut tidak hanya memahami teori dan memilih metode penelitian yang tepat, tetapi juga kemampuan untuk menulis secara ilmiah (Puspitasari, 2013). Sebagai bukti integritas serta implementasi teoritis, skripsi bermanfaat untuk memberikan dedikasi kepada masyarakat dengan seluruh ilmu yang diperoleh mahasiswa selama di perguruan tinggi.

Mansnur (2009) mendefinisikan bahwa skripsi adalah karya ilmiah yang ditulis mahasiswa program S1 yang membahas topik atau bidang tertentu berdasarkan hasil kajian pustaka yang ditulis oleh para ahli, hasil penelitian lapangan, atau hasil pengembangan (eksperimen). Penulisan skripsi merupakan suatu karya ilmiah yang mengajarkan mahasiswa untuk belajar mengkritisi suatu fenomena yang terjadi dalam kehidupan manusia secara ilmiah sesuai dengan ilmu yang didapat dalam disiplin ilmu masing-masing. Selain itu, penulisan skripsi juga sangat berguna bagi tenaga pendidik dan juga mahasiswa untuk mengetahui tingkat pengetahuan dan pemahaman mahasiswa akan ilmu pengetahuan yang didapat selama masa perkuliahan.

Pada dasarnya dalam menyususn skripsi, mahasiswa akan melakukan proses bimbingan skripsi kepada dosen pembimbing. Berdasarkan hasil wawancara masalah yang sering muncul dalam proses pengerjaan skripsi antara lain mahasiswa yang tidak fokus pada judul penelitiannya dan masih kesulitan dalam menyusun latar belakang permasalahan. Selain itu, rendahnya pengetahuan terhadap teori-teori serta metode penelitian juga sebagai kendala utama mahasiswa tingkat akhir dalam menyusun skripsi yang sistematis dan terstruktur.

Permasalahan tersebut tidak hanya menguji kecerdasan intelektual mahasiswa, namun juga menguji kecerdasan emosional mahasiswa. Dengan adanya kondisi seperti ini, bimbingan skripsi adalah metode yang tepat untuk mencapai hasil maksimal dan berkualitas dari penelitian ilmiah mahasiswa. Saat ini salah satu faktor yang menjadi penghambat mahasiswa dalam menyusun skripsi adalah kecemasan. Skripsi tetap menjadi pemicu stres yang dapat memunculkan kecemasan bagi sebagian mahasiswa khususnya bagi mahasiswa tingkat akhir. Setiap mahasiswa yang memiliki kecemasan akan dapat menurunkan kemampuan akademisnya karena akan mengganggu dan menurunkan kinerja memori ketika kecemasan itu muncul dalam diri individu (Minahan \& Rappaport, 2013).

Kecemasan yang semakin meningkat dapat menghambat komunikasi antara dosen pembimbing dan mahasiswa dalam bimbingan skripsi (Huerta, Goodson, Beigi \& Chlup, 2016). Interaksi dosen pembimbing dengan mahasiswa dalam bimbingan skripsi memerlukan peranan komunikasi yang dapat mempengaruhi kognitif, afektif, dan perilaku mahasiswa dalam menyelesaikan skripsinya (DeVito, 2012).

Hawari (2006), menjelaskan bahwa faktor yang mempengaruhi kecemasan tergantung pada struktur perkembangan kepribadian diri seseorang yaitu usia, jenis kelamin, tingkat pendidikan, dukungan sosial dari keluarga, teman dan masyarakat. Peranan dosen pembimbing diharapkan mampu mengurangi permasalahan yang akan dialami mahasiswa dalam proses pengerjaan skripsi, namun terdapat kondisi nyata dimana dosen pembimbing skripsi menjadi salah satu permasalahan bagi mahasiswa dalam proses pengerjaan skripsinya.

Mahasiswa merasa khawatir apabila akan bertemu dengan dosen pembimbing dan mengalami kecemasan berkomunikasi saat bimbingan skripsi. Berdasarkan latar belakang masalah di atas, maka peneliti melakukan penelitian mengenai kecemasan berkomunikasi mahasiswa dengan dosen pembimbing dalam proses bimbingan skripsi. Tujuan dalam penelitian ini untuk mengetahui kecemasan berkomunikasi mahasiswa dalam pengalaman interaksi komunikasi dengan dosen pembimbing dalam proses bimbingan skripsi. Selain itu, untuk mengetahui faktor-faktor yang berpotensi menjadi penyebab terjadinya kecemasan mahasiswa dalam interaksi komunikasi dengan dosen pembimbing dalam proses bimbingan skripsi. 


\section{METODE PENELITIAN}

Jenis penelitian yang digunakan adalah pendekatan kualitatif deskriptif dengan didasarkan pada data-data yang diperoleh di lapangan untuk kemudian dianalisis. Moleong (2007) mengemukakan bahwa penelitian kualitatif adalah penelitian yang bermaksud untuk memahami fenomena tentang apa yang dialami oleh subyek penelitian misalnya perilaku, persepsi, motivasi, tindakan dan lain-lain, secara holistik, dan dengan cara deskripsi dalam bentuk kata-kata dan bahasa, pada suatu konteks khusus yang alamiah dan dengan memanfaatkan berbagai metode alamiah.

Penelitian ini dilakukan di lingkungan Fakultas Ilmu Pendidikan (FIP) Universitas PGRI Semarang. Subjek penelitian ini meliputi mahasiswa FIP Universitas PGRI Semarang yang sedang melaksanakan proses bimbingan skripsi. Dalam penelitian ini teknik yang digunakan dalam pengambilan data adalah kuesioner, wawancara, dokumentasi dan observasi.

Teknik analisis data yang digunakan adalah dengan deskriptif analitik. Beberapa data yang dihimpuan dari lapangan dianalisis dan disajikan dalam bentuk deskripsi. Data hasil penelitian dianalisis menggunakan analisis deskriptif tanpa melalui analisis model presentase.

Teknik triangulasi yang digunakan dalam penelitian ini adalah teknik pemeriksaan dengan memanfaatkan penggunaan sumber berarti membandingkan dan mengecek balik derajat kepercayaan suatu informasi yang diperoleh melalui waktu dan alat yang berbeda.

\section{HASIL DAN PEMBAHASAN}

Hasil penelitian ini meliputi hasil observasi, hasil wawancara, hasil studi pustaka dan hasil dokumentasi yang kemudian dianalisis dan disajikan dalam deskripsi. Hal tersebut berguna untuk menjawab permasalahan yang terjadi pada lokasi penelitian diantaranya: 1) kecemasan berkomunikasi mahasiswa dalam pengalaman interaksi komunikasi dengan dosen pembimbing dalam proses bimbingan skripsi; 2) faktorfaktor yang berpotensi menjadi penyebab terjadinya kecemasan mahasiswa dalam interaksi komunikasi dengan dosen pembimbing dalam proses bimbingan.

\section{Kecemasan Berkomunikasi Mahasiswa dalam Pengalaman Interaksi Komunikasi dengan Dosen Pembimbing dalam Proses Bimbingan Skripsi}

Di dalam penelitian ini peneliti ingin mengetahui bentuk kecemasan yang dialami mahasiswa tingkat akhir di Fakultas Ilmu Pendidikan Universitas PGRI Semarang. Pengambilan data tentang kecemasan yang terjadi pada mahasiswa dilakukan dengan menggunakan wawancara, kuesioner dan observasi. Kecemasan merupakan hal yang wajar dialami bagi siapa saja, termasuk mahasiswa dalam menyelesaikan tugas akhir studi.

Berdasarkan wawancara yang dilakukan dengan responden diperoleh hasil bahwa tidak ada hal yang membuat responden merasa tidak nyaman saat melakukan proses bimbingan, namun responden merasakan takut dan waswas ketika bimbingan. Proses bimbingan skripsi juga membuat responden menjadi lebih sensitif, gelisah dan temperamen. Selain itu responden lain menyatakan bahwa dalam melakukan bimbingan skripsi kepada dosen mengalami kecemasan, akan tetapi tidak terlalu mengganggu. Namun, berdasarkan hasil wawancara mahaisiswa tersebut menyatakan bahwa mahasiswa merasa bersalah ketika bertemu dengan dosen pembimbing untuk proses bimbingan karena dia merasa dalam mengerjakan skripsi terburu-buru.

Hal di atas didukung dengan kuesioner yang telah dibagikan, dimana responden menyatakan mengalami kecemasan saat menyelesaikan skripsi berupa sering sakit kepala, sulit tidur, cepat merasa lelah, gelisah, dan mengganggu pikirannya. Begitu pula dengan responden lain mengungkapkan sering merasakan kebingungan dan frustasi ketika dosen dan teman tidak memberikan dukungan dan solusi terhadap permasalahan yang dihadapinya. Bahkan merasa depresi karena tuntutan dari orang tua yang ingin segera lulus. Selain itu, mahasiswa merasa frustasi terhadap diri sendiri ketika judul skripsi yang dipilih tidak didukung oleh dosen tanpa adanya pemberian solusi terhadap permasalahan skripsinya. Selain itu, responden juga mengalami kecemasan berupa sering merasa sakit kepala, susah tidur, gelisah, dan gugup jika berurusan dengan skripsi.

Dalam proses penyusunan skripsi, tentunya mahasiswa memiliki rasa kecemasan karena manusia mempunyai hati dan perasaan. Bentuk kecemasan tersebut dapat berupa ketidakpastian apakah ia mampu menyusun, dan menyelesaikan skripsi sebelum batas akhir 


\section{Husni Wakhyudin, dan Anggun Dwi Setya Putri \\ ANALISIS KECEMASAN MAHASISWA DALAM MENYELESAIKAN SKRIPSI \\ WASIS: Jurnal Ilmiah Pendidikan. Volume 1, Nomor 1, Mei 2020, hlm. 14-18}

kuliah. Tingkat kecemasan yang dialami mahasiswa berbeda-beda, rasa cemas akan sangat mempengaruhi konsentrasi dan daya pikir mahasiswa.

Daradjad (2001) menyatakan kecemasan pada mahasiswa akan menyebabkan mahasiswa cenderung minder, takut, gugup, dan bahkan ketika kecemasan dirasakan secara mendalam bisa membuat mahasiswa tertekan. Hal ini tentu akan sangat berpengaruh pada kondisi psikologis dan kepercayaan diri mahasiswa sehingga berpikir bahwa dirinya tidak mampu menyelesaikan skripsi sesuai dengan kemampuan yang dimilikinya.

\section{Faktor Penyebab Kecemasan Mahasiswa dalam Menyusun Skripsi}

Faktor penyebab kecemasan mahasiswa semester akhir dapat digolongkan menjadi dua faktor, yaitu faktor internal dan faktor eksternal. Faktor internal yaitu yang bersumber dari individu itu sendiri, sedangkan faktor eksternal yaitu faktor yang dipengaruhi dari luar individu. Faktor internal yang sering dialami oleh mahasiswa dalam penyusunan skripsi seperti: kesulitan dalam menyusun perumusan masalah, mengkonsep isi skripsi, teknik penulisan, isi dan metode penelitian yang digunakan, dan mencari sumber data, serta kesulitan dalam menuangkan tulisan ke dalam naskah skripsi. Selain itu, biaya pembuatan skripsi terutama bagi mahasiswa yang berasal dari kondisi keluarga dengan ekonomi keluarga yang pas-pasan merasa terbebani. Ada juga beberapa mahasiswa yang aktif dan terlena dalam kegiatan berorganisasi. Selain faktor internal tersebut, ada juga mahasiswa yang pesimis, malas-malasan, dan tidak bersemangat dalam menyelesaikan skripsi.

Faktor internal di atas didukung dengan hasil wawancara dan observasi yang telah dilakukan peneliti. Berdasarkan wawancara dengan beberapa responden menyatakan bahwa faktor-faktor yang mempengaruhi penyusunan dan pembimbingan skripsi berasal dari dalam dan luar. Seperti yang disampaikan beberapa responden berikut ini, menurut salah satu responden menyampaikan bahwa lingkungan sebagai salah satu factor yang berpengaruh terhadap mahasiswa dalam menyelesaikan skripsi, namun lingkungan sekitar kurang mendukungnya dalam menyelesaikan skripsi. Oleh karena itu, responden memerlukan tempat dan waktu khusus untuk mengerjakan skripsi meskipun masih kurang memadai.

Selain itu, berdasarkan pengamatan peneliti banyak responden yang ketika menyusun skripsi memerlukan tempat yang nyaman dan suasana yang mendukung. Biasanya mereka mengerjakan skripsi sekaligus mencari tempat yang memiliki akses internet. Atau sekalipun mereka mengerjakan di rumah atau di kos juga memerlukan waktu khusus, misalnya ketika sepi dan di waktu malam hari bahkan tengah malam. Jika hal tersebut tidak mendukung maka penyusunan skripsi pun akan terhambat karena muncul rasa tidak nyaman bagi diri responden.

Faktor lain yang berpengaruh terhadap penyelesaian skripsi adalah factor eksternal. Beberapa factor eksternal antara lain birokrasi kampus, misalnya: syarat kelulusan harus melalui beberapa syarat yang rumit. Dosen pembimbing dan dosen penguji, penguji yang terkenal sulit membuat mahasiswa ketakutan sebelum ujian berlangsung. Faktor lainnya yaitu kuliah sambil bekerja, tuntutan dari orang tua agar cepat menyelesaikan skripsi, dan deadline masa penulisan skripsi seperti batas akhir pendaftaran ujian. Belum jelasnya lapangan pekerjaan (masa depan) yang akan di tuju, ketatnya persaingan kerja, sempitnya lapangan pekerjaan, serta kenyataan alumni yang masih nganggur juga menjadi penyebab mahasiswa mengalami kecemasan terhadap masa depan mereka.

Faktor eksternal di atas didukung dengan hasil observasi yang dilakukan. Berdasarkan observasi terlihat bahwa faktorfaktor yang mempengaruhi penyusunan dan pembimbingan skripsi yang berasal dari luar dijabarkan sebagai berikut. Dalam proses bimbingan pembimbing sulit ditemui, proses bimbingan yang tidak menentu, bimbingan yang lama dan hanya memberikan sedikit waktu untuk bimbingan, dalam memberikan bimbingan kurang jelas, tidak terjadinya koordinasi yang baik antara pembimbing I dengan II, dan ketika melakukan bimbingan seringnya dosen pembimbing lebih berperan sebagai penguji awal dari pada sebagai partner diskusi, pembimbing hanya men-cari kesalahan tanpa memberikan solusi yang pasti.

Faktor yang dapat menyebabkan kecemasan dalam penyu-sunan skripsi adalah adanya suatu kesulitan atau hambatan yang dirasakan mahasiswa baik bersifat internal maupun eksternal. Faktor internal adalah kendala/kesulitan yang dialami mahasiswa dalam penyusunan skripsi yang bersum-ber dari diri sendiri seperti merumuskan masalah, mengkonsep isi skripsi, mencari data atau sumber-sumber yang terkait, dan menuangkan tulisan ke dalam naskah skripsi. 


\section{Husni Wakhyudin, dan Anggun Dwi Setya Putri \\ ANALISIS KECEMASAN MAHASISWA DALAM MENYELESAIKAN SKRIPSI \\ WASIS: Jurnal Ilmiah Pendidikan. Volume 1, Nomor 1, Mei 2020, hlm. 14-18}

Dengan kata lain kesulitan yang dialami mahasiswa dalam penyusun skripsi terletak pada penyusunan metodologi penelitian. Mahasiswa tidak begitu paham tentang metodologi penelitian, dan kebanyakan mahasiswa dalam menyusun metodologi hanya melihat dan mencocokan metodologi penulisan yang sudah pernah di tulis dalam skripsi yang sudah ada, dan belum tentu tepat. Kesulitan dalam penyusunan metodologi penelitian tersebut membuat mahasiswa semester akhir mengalami tekanan atau konflik batin yang pada akhirnya dapat menyebabkan kecemasan (Nur, 2008).

Kecemasan mahasiswa se-mester akhir bukan hanya dipengaruhi oleh faktor internal, tetapi dapat juga dipengaruhi oleh faktor eksternal. Banyak mahasiswa mengalami kecemasan ketika berurusan dengan birokrasi, menghadapi dosen pembimbing, dan penguji. Pada birokrasi misalnya, syarat kelulusan harus melalui beberapa syarat yang rumit, sehingga mahasiswa harus membagi pikirannya untuk me-nyelesaikan penulisan skripsi yang sudah sangat menguras otak dan sekaligus menyelesaikan syarat-syarat kelulusan diterapkan fakultas yang lain.

Di dalam konsultasi harusnya terjadi suatu pertukaran pikiran antara pembimbing dengan mahasiswa untuk mendapatkan nasehat, dan saran yang sebaik-baiknya. Namun dalam pelaksanaanya sering dosen pembimbing sulit untuk ditemui, hanya memberikan sedikit waktu untuk bimbingan, dalam memberikan bimbingan kurang jelas, bimbingan lama, tidak terjadinya koordinasi yang baik antara pembimbing I dengan II, dan ketika melakukan bimbingan seringnya dosen pembimbing lebih berperan sebagai penguji awal dari pada sebagai partner diskusi, pembimbing hanya mencarai kesalahan tanpa memberikan solusi yang pasti. Situasi seperti inilah yang akhirnya dapat menimbulkan kecemasan mahasiswa pada saat mau melakukan bimbingan skripsi dan membuat mahasiswa trauma bimbingan kembali.

\section{SIMPULAN}

Berdasarkan hasil penelitian dan pembahasan dari penelitian ini dapat disimpulkan bahwa:

1. Kecemasan berkomunikasi mahasiswa dalam pengalaman interaksi komunikasi dengan dosen pembimbing dalam proses bimbingan skripsi terjadi pada mahasiswa ketika menyusun maupun melakukan bimbingan skripsi. Hal tersebut mengakibatkan mahasiswa mengalami berbagai macam kecemasan, mulai dari sakit kepala, sulit tidur, cepat merasa lelah, gelisah, gugup, putus asa, depresi, pusing, pikiran menjadi kacau hingga berdampak pada orang lain sehingga menjadi sasaran kemarahan.

2. Faktor-faktor yang berpotensi menjadi penyebab terjadinya kecemasan mahasiswa dalam interaksi komunikasi dengan dosen pembimbing dalam proses bimbingan yakni faktor internal dan faktor eksternal. Faktor internal antara lain kendala/ kesulitan yang dialami mahasiswa dalam penyusunan skripsi, biaya pembuatan skripsi, terlena berorganisasi, pesimis, malas-malasan, dan tidak bersemangat. Sedangkan faktor eksternal yakni pembimbing sulit ditemui, proses bimbingan yang tidak menentu, bimbingan yang lama dan hanya memberikan sedikit waktu untuk bimbingan, dalam memberikan bimbingan kurang jelas, tidak terjadinya koordinasi yang baik antara pembimbing I dengan II, dan ketika melakukan bimbingan seringnya dosen pembimbing lebih berperan sebagai penguji awal dari pada sebagai partner diskusi, pembimbing hanya mencari kesalahan tanpa memberikan solusi yang pasti.

\section{DAFTAR PUSTAKA}

Devito, Joseph. 2011. Komunikasi Antarmanusia. Tanggerang Selatan: Karisma Publishing Group

Hawari, D. 2001. Manajemen Stress, Cemas dan Depresi. Jakarta: FK UI.

Mansur. 2009. Metode Penelitian Dan Teknik Penulisan Laporan Karya Ilmiah. Bandung: Universitas Padjajaran.

Minahan, Jessica dan Rappaport, Nancy. 2013. Anxiety in Students a Hidden Culprit in Behavior Issues. Kappan 94 (4). (Online),

Moleong, Lexy. 2007. Metode Penelitian Kualitatif, Bandung: PT.Remaja Rosdakarya.

Puspitasari, RT. 2013. Adversity Quotient Dengan Kecemasan Mengerjakan Skripsi Pada Mahasiswa. Jurnal Online Psikologi, 1 (1). 